\title{
IQTISHODUNA
}

IQTISHODUNA: Jurnal Ekonomi Islam

E-ISSN: 2443-0056, P-ISSN: 2252-5661

Accredited Number 21/E/KPT/2018

Volume 9 Issue 1, April 2020 | Page: 121-136

DOI: doi.org/10.36835/iqtishoduna.v9i1.478

\section{Profit Loss Sharing (PLS) and Its Implementation in Indonesian Islamic Banking}

\author{
Muhammad Anwar Fathoni ${ }^{1}$, Suryani ${ }^{2}$ \\ ${ }^{1}$ Departement of Islamic Economics, Faculty of Economics and Business, Universitas \\ Pembangunan Nasional Veteran Jakarta, Jl. RS. Fatmawati Raya Pd. Labu Kec. Cilandak Kota \\ Depok Jawa Barat 12450, Indonesia \\ ${ }^{2}$ Departement of Islamic Economics, Faculty of Islamic Economics and Business, Institut Agama \\ Islam Negeri Lhokseumawe Aceh, Jl. Medan - Banda Aceh Alue Awe Muara Dua Kota \\ Lhokseumawe Aceh 24352, Indonesia \\ e-mail: ${ }^{1} \underline{\text { mfathoni@upnvj.ac.id }}^{2}$ suryapijar@yahoo.com
}

\begin{abstract}
Writing this article aims to determine the concept of Profit Loss Sharing (PLS) and its implementation in Indonesian Islamic banking. The data used in this article is sourced from secondary data from books, scientific journals, sharia banking statistical data released by the Financial Services Authority (OJK) and other sources relevant to the focus of the discussion. The author finds that the application of the concept of profit loss sharing in mixing agreements is the antithesis of the concept of interest which has dominated the banking world. However, in practice, not all Islamic banking applies this concept. Even Islamic banking in Indonesia is more likely to choose revenue sharing to safeguard the interests of its customers. The author only uses secondary data to measure the implementation of PLS in Islamic banking, so that further research will be better if conducting primary data mining to get a broader picture related to the theme of the article.
\end{abstract}

Keywords: profit loss sharing, mixing agreements, islamic banking.

Abstrak: Penulisan artikel ini bertujuan untuk mengetahui konsep Profit Loss Sharing (PLS) dan implementasinya di perbankan syariah Indonesia. Data yang digunakan dalam artikel ini bersumber dari data sekunder yang berasal dari buku, jurnal ilmiah, data statistik perbankan syariah yang dirilis oleh Otoritas Jasa Keuangan (OJK) dan sumber lain yang relevan dengan fokus bahasan. Penulis menemukan bahwa penerapan konsep profit loss sharing dalam akad-akad percampuran merupakan antitesis dari konsep bunga (interest) yang selama ini mendominasi dunia perbankan. Namun, dalam prakteknya, tidak semua perbankan syariah menerapkan konsep ini. Bahkan perbankan syariah di Indonesia lebih cenderung memilih revenue sharing untuk menjaga kepentingan para nasabahnya. Penulis hanya menggunakan data sekunder untuk mengukur implementasi PLS di perbankan syariah, sehingga penelitian selanjutnya akan lebih baik jika melakukan penggalian data primer untuk mendapatkan gambaran lebih luas terkait tema artikel.

Kata kunci: Profit Loss Sharing (PLS), akad percampuran, perbankan syariah.

\section{Introduction}

At present, Indonesia occupies the first position as the country with the largest Muslim population in the world. ${ }^{1}$ This large Muslim market

\footnotetext{
${ }^{1}$ The total population of Indonesia based on the 2010 population census
}

share is an opportunity that should not be missed to develop businesses that are in accordance with Islamic teachings. Based on the assessment of the 2015 Global Islamic Financial

\begin{tabular}{lccc}
\hline reached & 237.6 & million. & See \\
http://www.bps.go.id & &
\end{tabular}


122 IQTISHODUNA: Jurnal Ekonomi Islam Volume 9 Issue 1, April 2020

Report (GIFR), Indonesia ranks sixth in the country with potential and conduciveness in the development of the Islamic financial industry after Iran, Malaysia, Saudi Arabia, United Arab Emirates, Kuwait and Bahrain. With such huge market potential, it is not impossible that Indonesia will one day become the center and center of the world Islamic economy. ${ }^{2}$

The islamic banking industry has experienced significant growth since the birth of government regulation in the form of UU No. 10 of 1998 concerning amendment of UU No. 7 of 1992 concerning Banking and UU No. 21 of 2008 concerning Islamic Banking. As of June 2015, the Islamic banking industry has a network of 12 Sharia Commercial Banks (BUS), 22 Sharia Business Units (UUS), and 161 Sharia People Financing Banks (BPRS), with a total network of offices reaching 2,881 offices spread across almost all of Indonesia. ${ }^{3}$ Of course, the development of Islamic banking has contributed greatly to the Indonesian economy. Even so, close supervision from the

${ }^{2}$ By looking at several aspects in calculating the index, such as the number of Islamic banks, the number of Islamic nonbank financial institutions, and the size of Islamic financial assets that have the greatest weight, Indonesia is projected to be ranked first in the next few years. See Halim Alamsyah's lecture in the Scientific Association of Islamic Economics (IAEI), IAEI 8th Anniversary, April 13, 2012, entitled "Development and Prospects of Indonesian Islamic Banking: Challenges in Welcoming the 2015 MEA".

3See Financial Services Authority, Islamic Banking Statistics, (2015). authorities is still needed so that the direction and objectives of the Islamic financial industry do not deviate from Islamic teachings.

slamic economics has principles and characteristics that are very much different from today's mainstream economy, namely the capitalist economy. According to Muchlis Yahya and Edy Yusuf Agunggunanto (2011), philosophically there are three things that characterize Islamic economics, namely the philosophy of religiosity that creates economics with the prohibition of usury, justice that raises the theory of profit loss sharing or profit sharing ratio, and benefit that gives birth to birth institutionalization of alms, prohibition of Israf and Tabdhir, ${ }^{4}$ and halal business financing demanded

\footnotetext{
${ }^{4}$ Israf is an act that exceeds the limit in using and spending wealth on a halal road. Whereas tabdhir is the act of using property other than its place so as to eliminate its usefulness in the world and the hereafter. Both of these actions are prohibited by Islam as stated in the QS. Al-An'am: 141, QS. Al-Furqan: 67, and QS. Al-Isra: 26-27. See Mahmud Abdul Karim Ershad, al-Madkhal ila al-Iqtishad alIslamiy, (Jordan: Dar al-Nafais, 2011), 316317.
} 
by the Falah philosophy, ${ }^{5}$ not utilitarianism and rationalism. ${ }^{6}$

On this occasion, the author will limit the discussion only to the problem of the theory of Profit Loss Sharing (PLS), fund collection and financing products and their development in Indonesian Islamic banking. This is done to focus this study more on the issue of how the development of PLS theory implementation in Indonesian Islamic banking. The data obtained is the result of library research from various books, journals, and other sources related to this study.

\section{Profit Loss Sharing Discourse}

Humans as social beings have consequences to always relate to each other. This relationship is created in various forms, in this context, the relationship between humans can occur in the form of cooperation in an effort to maintain life and improve welfare. The fact that sometimes someone has capital but is unable to manage it, and on the other hand there is someone who has the ability but does not have the capital, so the two have to do a

\footnotetext{
${ }^{5}$ Falah (welfare and success) which means prosperity and success in the afterlife, is a value that must be upheld in every economic activity. The measure of prosperity and success is certainly not how much profit is gained, but also must pay attention to ethical and moral aspects. See Mahabub Alom and Shariful Haque, "Marketing: An Islamic Perspective", World Journal of Society Sciences (2011), 71-81.

${ }^{6}$ Muchlis Yahya dan Edy Yusuf Agunggunanto, ,Teori Bagi Hasil dan Perbankan Syariah dalam Ekonomi Syariah', Jurnal Dinamika Ekonomi Pembangunan (2011), 65-73.
}

cooperative relationship to achieve these goals. Islam as a universal and comprehensive religion certainly regulates this. In muamalah fiqh discourse, known as profit sharing system or Profit Loss Sharing.

Profit Loss Sharing is a principle whereby profits or losses that may arise from the business carried out are borne jointly by the parties in the agreement. Angelo M Venardos (2012) said that the PLS model is a collaboration in which the related parties share profits (profit) and risk (risk) in accordance with the portion of capital and business. The principle of profit sharing ratio is no certainty of risks and benefits such as interest. However, what is done is profit and loss sharing based on the real productivity of the product. ${ }^{7}$

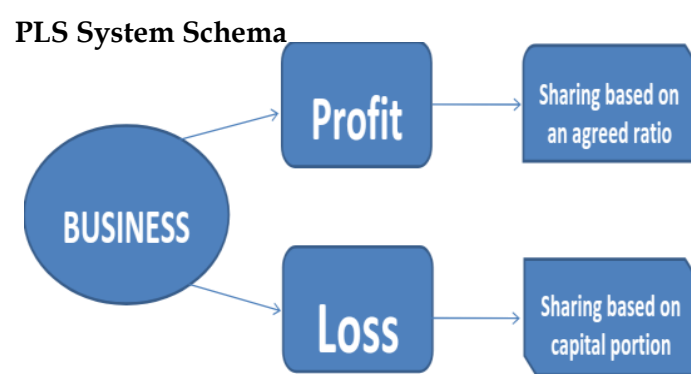

Information:

1. In terms of profit, sharing is based on a ratio agreement.

2. In terms of loss, sharing is based on a portion of capital.

In the PLS system, the price of capital is determined jointly through

${ }^{7}$ Angelo M Venardos, Islamic Banking \& Finance in South-East Asia: Its Development \& Future, (Singapore: B \& Jo Enterprise Pte Ltd, 3rd Edition, 2012), 34. 
124 IQTISHODUNA: Jurnal Ekonomi Islam Volume 9 Issue 1, April 2020

the role of entrepreneurship. Price of capital and entrepreneurship are inseparable and must be considered together in determining the price of production factors. Principal money that does not produce productivity is not subject to additional. The production sharing agreement is based on a percentage (ratio) of the actual productivity results obtained. The nominal amount of revenue sharing can be known after the results of the utilization of these funds already exist (ex post phenomenon, not ex ente). The profit sharing ratio is determined based on the agreement of the collaborating parties. Muchlis Yahya and Edy Yusuf Agunggunanto (2011) who cite Hendri Anto (2003) said in general the size of the ratio received was influenced by the contribution of each party in cooperation (share and partnership), the possibility of the benefits to be gained (expected return) and the possibility of risk that might happen (expected risk). ${ }^{8}$ In agreeing on the ratio, all three factors must be considered carefully. Starting with the first factor, share on partnership which is something tangible and measurable. Therefore, these factors do not require special attention. The next two factors, expected return, and expected risk require special attention because to estimate the

\footnotetext{
${ }^{8}$ Mathematically Hendri Anto formulated it as follows: $\mathrm{BH}=\mathrm{f}(\mathrm{S}, \mathrm{p}, 0)$ where $\mathrm{BH}$ : profit sharing, $\mathrm{S}$ : share on partnership, p: expected return, and 0 : expected risk. In terms of determining the profit sharing ratio, Adiwarman A. Karim said the following points must be considered
}

benefits and risks that may arise in cooperation in determining the profit sharing ratio, namely the reference profit margin and estimated profitability of the business being run. This profit margin reference can look at the rate of profit, while the estimation of business profitability must look at five aspects, namely sales estimate, duration of business (duration of the cash to cash cycle), estimated direct costs (estimated direct costs), estimated indirect costs and delayed factors. See Muchlis Yahya and Edy Yusuf Agunggunanto, Theory of Profit and Loss Sharing and Sharia Banking in Sharia Economics, 65-73 and Adiwarman A. Karim, Islamic Banking: Fiqh and Financial Analysis, (Jakarta: PT Raja Grafindo Persada, $3^{\text {rd }}$ edition, 2008), 283-286. which is based on PLS is absolutely needed, especially in the aspect of possible risks.

Risk can be estimated in a certain size, so it can be said that the ratio received is not always speculative. Risk means the consequences of productive activities. Keep in mind that the risk that must be avoided is the risk that cannot be estimated, such as passive risk or unknowables. In muamalah fiqh, this type of risk is known as gharar $^{9}$ which is purely speculative.

${ }^{9}$ Gharar or taghrir linguistically means danger (al-khatr), tends to damage (alta'rid li al-halak), deception (al-khida), obscurity (al-jahalah) or something that is born like but whose mind is hated. The elements of gharar are that the object which is the object of the contract is not in hand or owned, it is not known to exist, it cannot be submitted on time, resulting in 

and Its Implementation in Indonesian Islamic Banking

The occurrence of gharar is caused because someone does not (can) know at all the occurrence of a thing, giving rise to the nature of gambling (game of chance). In gambling, if one party gains, the other party loses. This shows the occurrence of win lose solution. In Islamic economics, a good transaction to do is a win-win solution that reflects the positive sum game contained in the principle of profit loss sharing. Based on the study in fiqh muamalah (sharia) bank interest is clearly classified in the scope of gharar. The reason is because the bank interest contained in the game of chance.

It is this uncertainty in terms of profit and loss that makes PLS included in the group of natural uncertainty contracts, namely contracts that do not provide certainty in terms of income (return) and loss (risk) in terms of the amount (amount) and time (timing) in business activities. Fathurrahman Djamil states, in a natural uncertainty contract the parties conducting business combine their assets (both real assets and financial assets) so that they become a single entity, then jointly bear the risk according to the agreement made. This type of business is an investment because there is no certainty about return at the beginning of the contract. ${ }^{10}$

the buyer experiencing loss, regret, and danger. See Fathurrahman Djamil, Hukum Ekonomi Islam: Sejarah, Teori dan Konsep (Jakarta: Sinar Grafika, cet. II, 2015), 166-169.

${ }^{10}$ Fathurrahman Djamil, Penerapan Hukum Perjanjian dalam Transaksi di
The unification of assets in a single unit is then called the theory of mixing (theory of venture). In Islamic law literature, this theory is known as shirkah or musharakah, which according to language means participation, taking part, cooperation, mixing or merging (ikhtilath). In terminology, there is cooperation between two or more people in certain business or economic activities to obtain mutual benefits with the terms and conditions agreed upon together. ${ }^{11}$

\section{PLS as Antithesis of the Interest System}

The prohibition of usury is one of the principles in Islamic economics. ${ }^{12}$ This prohibition can be found clearly in the Qur'an and asSunnah. Although Muslim scholars have different opinions about the legality of the interest system in banking, the majority say that the existing interest system in banking is an embodiment of usury that is

Lembaga Keuangan Syariah, (Jakarta: Sinar Grafika, 2013), 100.

${ }^{11}$ Abdul Manan, Hukum Ekonomi Syariah dalam Perspektif Peradilan Agama, (Jakarta: Kencana, 2012), 111-112.

${ }^{12}$ There are two tendencies when talking about usury. First usury is defined as an addition to loans originating from excess of the principal value provided to the debtor. Second, usury is understood as an activity that causes exploitation and injustice, which economically has a very detrimental impact on society. Although there are differences in determining the elements and background forbidden usury, both meanings have a perception in which usury is considered to contain elements that are detrimental to the other party. See Fatfurrahman Djamil, Hukum Ekonomi Islam: Sejarah, Teori dan Konsep, 159-165. 
forbidden by Islam. Muhammad Syafii Antonio (2001) who agrees with this last opinion says usury has a negative impact on the economic and social life of the community. Riba plays an important role in inflation caused by interest as a cost of money because interest rates are used as a determinant of prices. In a sense, if the interest rate is higher then the price of an item that is already determined is also higher. This also applies to developing countries' debt to developed countries which is getting higher so that it harms developing countries. Debt must continue to be done by developing countries to pay interest and principal. Of course this will have an impact on the level of social life.

Islam commands humans to always do justice to their fellow human beings. This justice must be carried out also in economic life. Therefore, justice must be upheld by every business actor or business. ${ }^{13}$ Economic justice can be implemented as a whole, both in determining prices, product quality, treatment of workers, as well as the division of work portions and results of operations. In this case, the principle of profit sharing or profit loss (PLS) is a basic characteristic of Islamic economics that should be run by Islamic financial institutions, especially Islamic banking in Indonesia. The principle of profit sharing shows more justice than the interest system. In revenue sharing, benefits and risks are seen as Nahl: 90. something that can happen in the future. Meanwhile, the interest system only recognizes profit (profit) without considering the risks to the use of money. The use of PLS systems also prevents the occurrence of speculative actions that exist in the interest system. ${ }^{14}$

The concept of Islamic banking is based on the doctrine that Islam forbids usury and legalizes the sale and purchase and the sharing of profits from business cooperation or profit loss sharing. Since the interest system is classified as usury, Islamic banking offers the PLS system as an alternative to conducting business cooperation transactions.

The interest system is considered not a solution to various public financial problems. Islamic banks make a profit from the profit sharing ratio of banks as mudharib and banks as shohibul maal. During this time the ratio between banks as mudharib with customers is very dependent on the level of profit sharing ratio of banks as shohibul maal. ${ }^{15}$ The interest system is considered not a solution to various public financial problems. On the contrary, this system is very detrimental to the economic life of the people and the country. At least

14Shahrukh Rafi Khan, ,Profit and Loss Sharing as a Substitute for Interest in Islamic Banking', Journal of Savings and Development, Vol. 11, No. 3 (1987), 317-328.

${ }^{15}$ Fathurrahman, A. Meninjau Ulang Penerapan Fractional Reserve Banking pada Perbankan Syariah. IQTISHODUNA: Jurnal Ekonomi Islam, Vol 7(April, 2018), 185-210.

Retrieved from http: / / ejournal.iaisyarifuddin.ac.id/in dex.php/iqtishoduna/article/view/231 

and Its Implementation in Indonesian Islamic Banking

five logical reasons for Islamic banking to use PLS and leave the interest system: 16

1. Transactions with the interest system can damage the economic equity aspects of a business.

2. The interest system can kill innovation, especially for small companies because of the obligation to pay the principal debt and interest without regard to the company's financial condition.

3. Banks are only interested in raising public capital with interest because they are only interested in satisfying themselves and maximizing profits without caring about their business partners when financial turmoil occurs.

4. The interest system can reduce investment activities because of the burden of investment costs. If interest rates are raised because of monetary policy, private investors will receive large losses that cause stagflation.

5. The interest system puts forward security oriented rather than growth orientation. This causes restrictions on lending only for the interests specified by the bank.

\footnotetext{
${ }^{16}$ Angelo M Venardos, Islamic Banking \& Finance in South-East Asia: Its Development \& Future, 31-32.
}

Whereas the PLS system has characteristics that are contrary to the interest system. Are as follows: ${ }^{17}$

1. Based on risk and return sharing. The agreement regarding the profit sharing ratio when the contract is based on the consideration of the risk of profit and loss.

2. Distribution ratio based on the benefits obtained. Percentage value is determined based on the contribution of each party, the likelihood of the benefits and the level of risk that may occur.

3. Nominally, the amount of profit generated will fluctuate according to the real benefits derived from the use of funds.

4. The existence of PLS is very much in accordance with Islamic values which uphold justice.

\section{PLS in Natural Uncertainty Contracts}

In figh literature, PLS theory is used in natural uncertainty contracts, namely mudharabah and musharakah contracts. Both of these contracts are manifestations of trust contracts (al-'uqud al-amanah). To clarify the PLS application in the two contracts, the authors will discuss one by one.

\section{Trust Financing (Akad Mudharabah)}

${ }^{17}$ Muhammad Syafi'i Antonio, Bank Syariah: Dari Teori Ke Praktek, (Jakarta: Gema Insani Press, 2001), 90-100. 
128 IQTISHODUNA: Jurnal Ekonomi Islam Volume 9 Issue 1, April 2020

In Language, mudharabah ${ }^{17}$ comes from the Arabic word dharb which means to hit or knock the feet on the earth to run a business. In terms of terminology, experts are different editors in defining 18 mudharabah. Hanafiyah Ulama defines mudharabah as a contract of cooperation (shirkah) to benefit where one party contributes to capital and the other party contributes to capital management. While Mahmud alSharbiniy (1999) defines it as a process of involving capital with known amount and nature (al-qadr wa al-shifat) to the person who manages it, with the results (al-ribhh) divided by two which are divided, not nominal certain (al-nisbah duna al-qadr). ${ }^{19}$ Technically mudharabah is a business collaboration between two parties where the first party (shahib al-mal) provides the entire capital, while the second party becomes the manager (mudarib). ${ }^{20}$

Adiwarman A. Karim (2008) said that the practice of mudharabah had been carried out by Arabs well before the arrival of Islam. Before being sent as an apostle, Muhammad made this contract with

${ }^{18}$ Mudharabah is also called qirad or muqaradhah. The term mudharabah is often used by Iraqis, while the term qirad or muqaradhah is commonly used by the Hijaz. See Wizarah al-Auqaf, al-Mausu'ah al-Fiqhiyah al-Kuwaitiyah, (Kuwait: Dar al Shafwah, juz 38, 1998), 35.

${ }^{19}$ Mahmud al-Syarbiniy, Taammulat fi al-Shariah al-Islamiyah, (Cairo: Al-Haiah al-Mashryah al-'Amah li al-Kitab, 1999), 112.

${ }^{20}$ Muhammad Syafi'i Antonio, Bank Syariah: Dari Teori Ke Praktek, 95-98.
Khadijah, where Muhammad was a worker (mudharib) and Khadijah as the owner of capital (shahib al-mal). In practice, Khadijah as the owner of capital gave full trust to Muhammad who had the ability to manage capital. After Muhammad was sent as a prophet and apostle, this kind of business tradition continued, known by the Prophet Muhammad. and allowed by him. ${ }^{2122}$

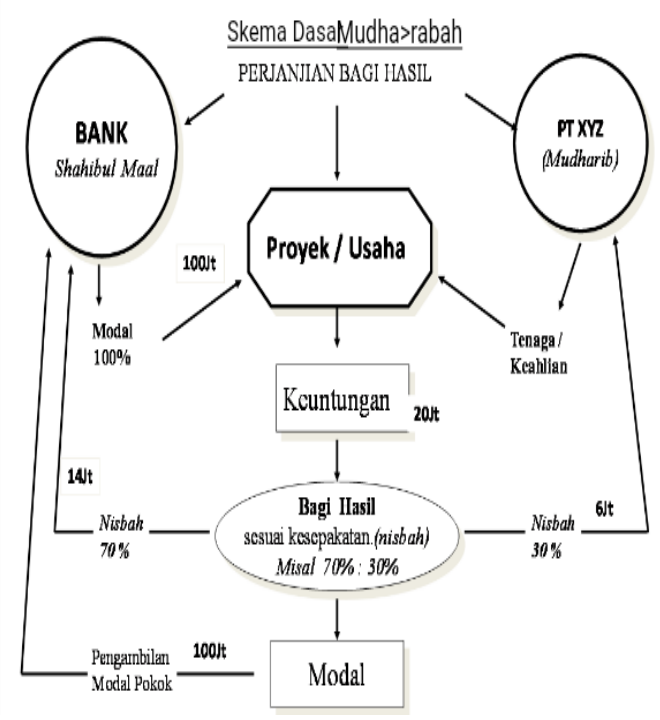

As the author pointed out above, the mudharabah agreement uses the principle of profit sharing or profit loss sharing. The profits from the business are divided based

${ }^{21}$ The basis for obtaining this agreement is QS. Al-Muzzammil: 20, alJumu'ah: 10, and al-Baqarah: 198, the hadith of Ibn Abbas ra. about mudaraba conducted by al-Abbas bin Abdul Muttallib, and ijma. See Wizarah alAuqaf, al-Mausu'ah al-Fiqhiyah alKuwaitiyah, (Kuwait: Dar al-Shafwah, juz 38, 1998), 37. and Adiwarman A. Karim, Islamic Banking: Fiqh and Financial Analysis, (Jakarta: PT Raja Grafindo Persada,

22 rdedition, 2008), 196-197. See too

Fatwa 07/DSN-MUI/IV/2000 about Mudharabah Financing (Qiradh). 

and Its Implementation in Indonesian Islamic Banking

on the agreement as stated in the contract. Profit is the amount obtained as excess of capital. Some things that must be considered related to the profit of this contract: 23

1. Profits are shared by both parties.

2. Profit sharing is expressed as a percentage (eg $70 \%$ for mudarib and $30 \%$ for shahib al-mal) of the profit that may be generated.

3. Determination of the percentage ratio (ratio) must be done through negotiations which are then set forth in the contract.

4. Distribution of profits made after mudharib return all or part of capital.

5. If the term of the mudaraba agreement is long, then the profit ratio can be renegotiated from time to time.

6. Determination of profits is calculated based on net profit.

Whereas when a loss occurs, it is borne proportionally from the amount of capital by Shahib al-mal, and mudarib does not receive any remuneration for work and business. In another sense, both parties will accept the risk of loss. However, if the loss caused by fraud or negligence mudarib, then he must be responsible for the loss. This is because the mudharabah contract is a type of contract that uses the

${ }^{23}$ Fathurrahman Djamil, Penerapan Hukum Perjanjian dalam Transaksi di Lembaga Keuangan Syariah, 175-176. principle of trust (yad al-amanah) and is trustworthy.

This principle of trust will change to the principle of guarantor of funds (yad al-dhamanah) when mudharib deliberately violates the terms or purpose of the contract. Likewise if he violates the restrictions set by Sahib al-mal, then he must take full responsibility for the losses suffered, and the mudharabah fund becomes a debt that must be paid by mudarib.

Mudharabah itself is of two types, namely mudharabah muthlaqah and mudharabah muqayyadah. Borrowing Adiwarman A. Karim. mudharabah muthlaqah or Unrestricted Investment Account here is that cooperation is not limited by the type of business, time and business area. Conversely, mudharabah muqayyadah or restricted investment account is a form of cooperation that is limited by the type of business, time, or place of business. In practice in Islamic banking, there are two types of restricted investment accounts, namely off-balance sheets and onbalance sheets. ${ }^{24}$

\footnotetext{
${ }^{24}$ In practice, sharia bank transactions with off-balance sheets only receive funding from one investor to then be distributed to one other customer who needs to be managed in a particular field. In this case, the bank is only an arranger. As for the onbalance sheet transaction, the bank receives funds from an investor to be subsequently invested in a predetermined joint (a group of business) such as manufacturing, agriculture, and so on. See Adiwarman A. Karim, Islamic Banking: Fiqh and Financial Analysis, 205-206.
} 
130 IQTISHODUNA: Jurnal Ekonomi Islam

Volume 9 Issue 1, April 2020

Mudharabah Type Scheme

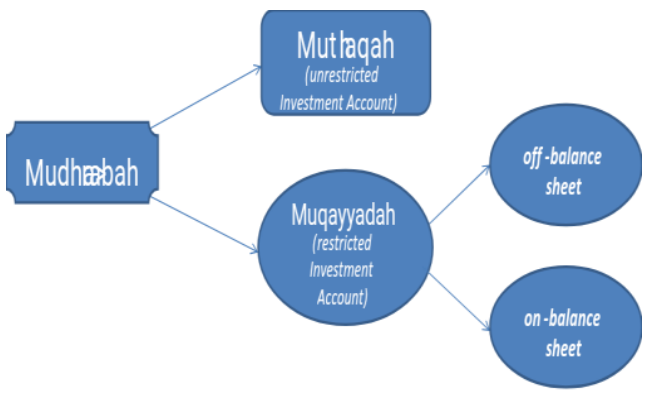

Furthermore, mudharabah contract applications in Islamic banking are available in various forms of financing products as well as funding. ${ }^{25}$ For fund raising, Mudharabah is generally used in the following products:

1. Term savings, is. savings with a period of time in which the funds are withdrawn, so that the funds saved cannot be withdrawn at any time. Usually time deposits are intended for special purposes, such as pilgrimage savings, sacrifice savings, and so on (regular deposits).

2. Special deposits, are deposits in which the funds deposited by customers are only intended for certain businesses, such as murabahah or ijarah.

In Islamic banking financing, products that commonly use mudaraba contracts are as follows:

1. Working capital financing, such as working capital for trade and services.

2. Special investment, also called mudharabah muqayyadah in two forms, namely off-

25 Muhammad Syafi'i Antonio, Bank Syariah: Dari Teori Ke Praktek, 95. balance sheet in which the bank is only an intermediary between the first and third parties, and on-balance sheet with the bank as mudharib.

Joint Venture Profit Sharing (Akad Musharakah)

Musharakah or shirkah according to language means a mixture of something with another that is difficult to distinguish. In terms of terminology, although fiqh experts disagree about the definition of musharakah, but have a substantive similarity, namely a form of cooperation between two or more parties for a particular business or business, where each party contributes in the form of funds or other assets provided that the benefits and risks will be borne together in accordance with the agreement. ${ }^{26}$ It can be understood from the above definition that the musharakah contract scheme shows that each party contributes to the capital. They agreed to do profit loss sharing.

Related to the law and its sharia foundation, the scholars say that it is permissible to use the musharakah contract in a business. The legal basis in the Qur'an can be seen in the QS. Al-Nisa verse 12 which means: "Then they are a third of the union". Likewise QS. Shad

${ }^{26}$ This definition is also substantively the same as the definition given by the MUI National Sharia Board (DSN). See fatwa DSN MUI about Musharakah Financing number 08/DSN-MUI/IV/2000 and Fathurrahman Djamil, Penerapan Hukum Perjanjian dalam Transaksi di Lembaga Keuangan Syariah, 165. 

and Its Implementation in Indonesian Islamic Banking

verse 24 which means: "And verily from the people who are in association some of them do wrong to others except those who believe and do good works". In the hadith duqsi narration of Abu Dawud also from Abu Hurairah ra. No. 2936 also illustrates that Allah. love His servants who make friendship while upholding the mutual mandate together and avoid betrayal. ${ }^{27}$

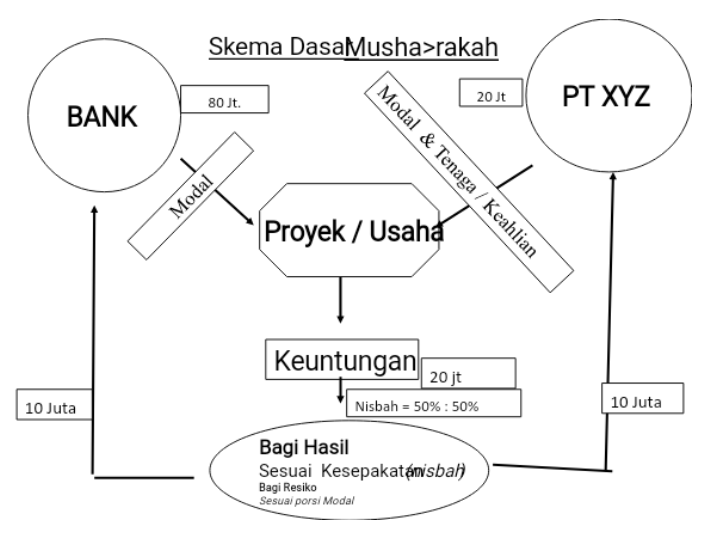

Shirkah or musharakah itself is divided into two, namely shirkah alamlak (union in ownership) that can be achieved because of inheritance, will, or other conditions that result in ownership of one asset by two or more people. Second is shirkah alququd (union based on agreement) which is created by making an agreement between two or more people where each party contributes capital and will share profits and losses. There are at least five types of the Shirkah al-ququd contract known in the classical fiqh literature, namely al-inan, al-mufawadhah, ala'mal, al-wujuh, and al-mudharabah. But on its way there was innovation

${ }^{27}$ Muhammad Syafi'i Antonio, Bank Syariah: Dari Teori Ke Praktek, 90-91. so as to bring up a contract which was named Musharakah mutanaqishah. ${ }^{28}$

Regarding the rules for the distribution of business results, the PLS system in the musharakah and mudharabah contracts is substantially the same. It's just a little difference between the two in terms of the distribution of risk or loss. If in the mudharabah agreement, the types of risks borne between shahib al-mal and mudarib are different. Shahib almal will bear the loss or depreciation

${ }^{28}$ The first two types of shirkah have similarities in the types of capital included, which are both contributing financial capital. The difference between the two is the portion of capital included in the assets. If the capital portion is adjusted according to the agreement of related parties, for example $30: 70$ or $40: 60$, then Syirkah mufawadhah requires related parties to include the same amount of capital (eg 50:50), work, and responsibility. The next two types of shirkah have similarities in the type of capital, namely power. The difference, if shirkah ala'mal or al-abdan is the collaboration of two people in the profession to accept work that is work (such as carpentry, workshops, etc.) together and share the benefits of the work, while shirkah al-w Tujuh is cooperation between two or more parties with capital from outside these parties. That is, one person gives capital to two or more people who act as mudharib. They buy goods using a good name and repitations without both having any financial capital at all, then sell them and the results are shared. The musharakah mutanaqishah is a form of cooperation in which one of the parties in the contract transferred the ownership of its shares to another party (divested). Transfer of ownership can be done in stages so that eventually the ownership rights are taken as a whole. See Abdul Manan, Hukum Ekonomi Islam dalam Perspektif Kewenangan Peradilan Agama, (Jakarta: Kencana, 2012), 117-130 
132 IQTISHODUNA: Jurnal Ekonomi Islam

Volume 9 Issue 1, April 2020

on the included capital and mudarib bears the risk of not getting a salary from his efforts in managing the business (except losses due to negligence of mudarib, capital is his responsibility). As for the PLS system, the type of musharakah agreement is the same type of profit and risk (loss). In a sense, each party will benefit according to the agreed profit ratio, whereas if there is a depreciation or even loss, then the risk will be borne together according to the portion of capital. To facilitate understanding of this matter, it can be seen in the following table:

\section{PLS System Table in Mudharabah and Musharakah}

\begin{tabular}{c|l|l}
\hline Category & Mudharabah & $\begin{array}{l}\text { Musharak } \\
\text { ah }\end{array}$ \\
\hline \multirow{5}{*}{ Profit } & $\begin{array}{l}\text { Divided based on } \\
\text { agreed percentages } \\
\text { between related } \\
\text { parties (based on } \\
\text { agreed ratio) }\end{array}$ & $\begin{array}{l}\text { Divided } \\
\text { based on } \\
\text { agreed } \\
\text { percentage } \\
\text { s between } \\
\text { related } \\
\text { parties } \\
\text { (based on } \\
\text { agreed } \\
\text { ratio) }\end{array}$ \\
\hline \multirow{5}{*}{ Loss } & $\begin{array}{l}\text { Shahib al-mal bears } \\
\text { the risk of loss or } \\
\text { depreciation of } \\
\text { capital. Mudharib } \\
\text { did not get } \\
\text { remuneration from } \\
\text { the efforts made }\end{array}$ & $\begin{array}{l}\text { Borne by } \\
\text { all relevant } \\
\text { parties } \\
\text { according } \\
\text { to the } \\
\text { portion of } \\
\text { capital } \\
\text { included }\end{array}$ \\
\hline
\end{tabular}

This Musharakah is usually used by Islamic Financial Institutions (LKS) in two forms, namely project financing and venture capital. In project financing products, customers and banks contribute funds to each other to finance a particular project. After the project is completed, the customer is obliged to return the financing funds along with the results according to mutual agreement. Venture capital usually uses a musharakah mutanaqishah financing scheme where investments are made within a certain period of time, then the bank will divest or sell its shares either in a short or gradual time. ${ }^{29}$

\section{Development of PLS in Indonesian Islamic Financial Institutions}

In this section, the author will explain several things related to the development of the PLS system in Indonesian Islamic banking. To find out this, the author will explain data from the Financial Services Authority (OJK) related to mudharabah and musharakah contracts used in financing and funding in Islamic financial institutions. The author will use the financial data of Islamic Commercial Banks (BUS), Sharia Business Units (UUS), and Islamic People's Financing Banks (BPRS) to analyze the development of the PLS system in Indonesian Islamic banking.

As the writer said at the beginning of this paper, Islamic banks were officially established in Indonesia in 1992 with the establishment of Bank Muamalat

${ }^{29}$ According to Fathurrahman Djamil, quoting Ahmed Ali Abdallah, musharakah can also be applied in sharia banking in several forms, including permanent musharakah, musharakah for working capital, decreasing musharakah or dimishing musharakah, and musharakah used for central bank market operating instruments. See Fathurrahman Djamil, Penerapan Hukum Perjanjian dalam Transaksi di Lembaga Keuangan Syariah, 170172. 

and Its Implementation in Indonesian Islamic Banking

Indonesia. This year, Islamic banks also received support from the government with the passing of UU No. 7 of 1992 concerning Banking. Bank Muamalat Indonesia (BMI) which is the first bank to spearhead the banking financial system based on the PLS system in several financial products. The trend of banking with a non-interest system (non-interest) is then getting a positive response from the public and finally led to some Islamic banking afterwards. OJK data states that in 2009 (one year after the enactment of UU No. 21 of 2008 concerning Sharia Banking), the BUS network in Indonesia numbered 6 banks with a total of 711 offices, UUS amounted to 25 banks with 287 offices and BPRS totaled 138 banks with 225 offices. Thus, the large number of Islamic banking at that time was 169 banks with 1,223 offices.

Six years later the world of Islamic banking in Indonesia experienced significant development. The latest data from the OJK as of June 2015 stated that the BUS network in 2015 totaled 12 banks with 2,121 offices, UUS totaling 22 banks with 327 offices, and BPRS totaling 161 banks with 433 offices. So that the total number of Indonesian Islamic banking in 2015 was 195 banks with 2,881 offices. This does not include nonbanking sharia businesses which have also developed rapidly to date, such as the emergence of the trend of Religious Tourism, Sharia Hotels, Panin Sharia, and so on. For more details, see the following table.
Indonesia Sharia Banking Development Table

\begin{tabular}{|c|c|c|}
\hline \multirow{2}{*}{ Indicator } & \multicolumn{2}{|c|}{ Year } \\
\hline & 2015 & 2019 \\
\hline $\begin{array}{l}\text { Sharia } \\
\text { Commercial } \\
\text { Bank (BUS) } \\
\text { - Number } \\
\text { of Bank } \\
\text { - Number } \\
\text { of Office }\end{array}$ & $\begin{array}{l}12 \\
2.121\end{array}$ & $\begin{array}{l}14 \\
1.885\end{array}$ \\
\hline $\begin{array}{l}\text { Sharia } \\
\text { Business } \\
\text { Unit (UUS) } \\
\text { - Number } \\
\text { of } \\
\text { Conventi } \\
\text { onal } \\
\text { Banks } \\
\text { with } \\
\text { UUS } \\
\text { - Number } \\
\text { of Office } \\
\end{array}$ & $\begin{array}{l}22 \\
327\end{array}$ & $\begin{array}{l}20 \\
375\end{array}$ \\
\hline $\begin{array}{l}\text { Islamic } \\
\text { People's } \\
\text { Financing } \\
\text { Bank (BPRS) } \\
\text { - Number } \\
\text { of Bank } \\
\text { - Number } \\
\text { of Office }\end{array}$ & $\begin{array}{l}161 \\
433\end{array}$ & $\begin{array}{l}165 \\
469\end{array}$ \\
\hline $\begin{array}{l}\text { Number of } \\
\text { Office }\end{array}$ & 2.881 & 4.830 \\
\hline
\end{tabular}

From these data, it can be concluded that the Islamic economic system which has been displaced by the capitalist system for a long time has begun to be recognized by Indonesia's predominantly Muslim community. According to Halim Alamsyah (2012), there are a number of factors that have significantly 
134 IQTISHODUNA: Jurnal Ekonomi Islam Volume 9 Issue 1, April 2020

boosted the performance of the Islamic banking industry in terms of raising funds and channeling financing. First, the expansion of the Islamic banking office network. The expansion needs to be done because the closeness of the office and easy access is one of the considerations of customers to open an account at an Islamic bank. Second, promoting education and socialization programs to the public regarding Islamic banking products and services. This factor will further increase public awareness and interest in Islamic banks. Third, improving the quality of service (service excellence) of Islamic banking so as not to lose out to conventional banking. One effort that can be done is the use of information technology access, such as the Automatic Teller Machine (ATM), mobile banking and internet banking. The fourth factor is the ratification of laws related to Islamic banking so as to provide legal certainty which can then increase the activities of Islamic financial markets, such as: UU no. 21 of 2008 concerning Islamic Banking, UU no. 19 of 2008 concerning State Sharia Securities (sukuk), and UU no. 42 of 2009 concerning the Third Amendment to UU No. 8 of 1983 concerning PPN on Goods and Services. ${ }^{30}$ After knowing the development of Islamic banking assets in Indonesia, let's look at the

${ }^{30}$ Halim Alamsyah in a lecture on the 8th Anniversary of the Scientific Association of Islamic Economics (IAEI), April 13, 2012, entitled, Development and Prospects of Indonesian Sharia Banking: Challenges in Welcoming the MEA 2015 ; 3-4. composition of financing conducted by Indonesian Islamic financial institutions. This is done to determine the position and development of the use of the PLS system in mudharabah and musharakah contracts in Islamic banking.

In 2015, the amount of financing using the Mudharabah and Musyarakah agreements on BUS and UUS was recorded at 203.894 trillion rupiah. Of this amount, the mudharabah contract contributed 14.906 trillion rupiah or $7.31 \%$ of total financing, and the musharakah contract reached 54.033 trillion rupiah or $26.50 \%$ of the total financing. The amount of financing in the BPRS reached 5.561 trillion rupiah with mudharabah contracts totaling 158.936 billion rupiah or $2.85 \%$ of the total financing and the musharakah contract reached 613.206 billion rupiah or $11.02 \%$ of total financing. ${ }^{31}$

Meanwhile, as of January 2019, total financing in BUS and UUS with Mudharabah and Musyarakah contracts tended to decrease. The total financing for BUS and UUS in early 2019 with the contract only reached 158.202 trillion rupiah. The total financing with the contract at the BPRS also experienced a downward trend. Achieved at the beginning of 2019 only reached 986.050 billion rupiah. For easy understanding see the following table.

31See Financial Services Authority, Islamic Banking Statistics, (2015), 18-19. 

and Its Implementation in Indonesian Islamic Banking

Financing Table in Islamic Banking

\begin{tabular}{l|l|l|l|l}
\hline $\begin{array}{l}\text { Type of } \\
\begin{array}{l}\text { Agreem } \\
\text { ent }\end{array}\end{array}$ & $\begin{array}{l}\text { BUS \& } \\
\text { UUS }\end{array}$ & BPRS & $\begin{array}{l}\text { BUS \& } \\
\text { UUS }\end{array}$ & $\begin{array}{l}\text { BP } \\
\text { RS }\end{array}$ \\
\hline $\begin{array}{l}\text { Mudha } \\
\text { rabah }\end{array}$ & $\begin{array}{l}14,906 \\
\mathrm{~T}\end{array}$ & $\begin{array}{l}158,93 \\
6 \mathrm{M}\end{array}$ & $\begin{array}{l}143,37 \\
8 \mathrm{~T}\end{array}$ & $\begin{array}{l}179 \\
, 66 \\
2 \mathrm{M}\end{array}$ \\
\hline $\begin{array}{l}\text { Musha } \\
\text { rakah }\end{array}$ & $\begin{array}{l}54,033 \\
\mathrm{~T}\end{array}$ & $\begin{array}{l}613,20 \\
6 \mathrm{M}\end{array}$ & $\begin{array}{l}14,824 \\
\mathrm{~T}\end{array}$ & $\begin{array}{l}806 \\
, 42 \\
8 \mathrm{M}\end{array}$ \\
\hline $\begin{array}{l}\text { Accum } \\
\text { ulation }\end{array}$ & 203,894 & 5,561 & $\begin{array}{l}158,20 \\
2 \mathrm{~T}\end{array}$ & $\begin{array}{l}986 \\
, 05 \\
0 \mathrm{M}\end{array}$ \\
$\begin{array}{l}\text { Entire } \\
\text { Akad }\end{array}$ & $\mathrm{T}$ & $\mathrm{T}$ & & \\
\hline
\end{tabular}

From the explanation of the data above, we can draw a conclusion that the contribution of financing products with Mudharabah and Musyarakah contracts is still relatively low, and even tends to decrease in the last 5 years. This is certainly very ironic considering the two contracts are a reflection of productive economic activities.

On the other hand, not all Islamic banks use the PLS system. Bank Syariah Mandiri (BSM), for example, in financing provided to customers, the BSM prefers to use revenue sharing rather than profit loss sharing (PLS). ${ }^{32}$ Hal ini bisa dipahami jika dilihat dari perspektif banker yang selalu berorientasi pelanggan (customer oriented) dan ingin memberikan kepuasan pada nasabah agar nasabah tidak lari ke bank lain.

In addition, this also indicates that both parties, both Islamic banking and customers are not ready to implement natural uncertainty contracts that basically use the

\footnotetext{
32See http:/ / www.syariahmandiri.co.id
}

principle of trust. To overcome this, a good and integrated management and control system is needed to foster mutual trust and trust between the two parties. Humayon and Presley (2001) who conducted research in the UK on the relationship between PLS and Management and Control stated that the application of the PLS model in Islamic banking is highly dependent on the application of management and control points. Both of these are very important because to avoid intensive fraud over the use of the contract with the PLS model. The practice of concealing information must also be eliminated because it negatively influences the application of the PLS model. In addition, the system that causes the development of revenue sharing instruments does not have a negative influence on the implementation of the PLS model in Islamic banking. ${ }^{33}$

\section{Closing}

From the above explanation it can be concluded several things related to the Profit Loss Sharing (PLS) system, i.e.:

1. PLS is a system of sharing profits and losses from the results of joint ventures that are trustworthy and uphold the principle of justice.

2. The PLS system is applied in two types of natural uncertainty

${ }^{33}$ Humayon A. Dar and John R. Presley, ,Lack of Profit Loss Sharing in Islamic Banking: Management and Control Imbalances', International Journal of Islamic Financial Services, Vol. 2, No.2 (2011). 
136 IQTISHODUNA: Jurnal Ekonomi Islam Volume 9 Issue 1, April 2020

contracts, namely mudharabah and musharakah in various variants. Both contracts are used by Islamic banking in various financing and financing products.

3. As a financial institution that uses the Islamic financial system, the implementation of the PLS system in Islamic banking is still not optimal. Not all Islamic banks use the PLS system in their financing products, some use the revenue sharing system more. Good management and control are needed to foster a culture of honesty and mutual trust between banks and customers, given that the PLS system is a revenue sharing system that uses the principle of trust.

At the end of this simple paper, the writer is well aware of the many shortcomings in both the writing and content of the article. For further research related to Profit Loss Sharing (PLS), field observations can be carried out to see firsthand the implementation and development of the PLS system in Islamic banking in order to obtain valid data and extensive analysis. Finally, the author is very open to constructive criticism and suggestions for the improvement and perfection of this article.

\section{REFERENCES}

Alamsyah, Halim, Perkembangan dan Prospek Perbankan Syariah Indonesia: Tantangan Dalam Menyongsong MEA 2015, disampaikan pada acara Milad ke8 Ilmiah Ikatan Ahli Ekonomi Islam (IAEI), 13 April 2012.

Alom, Mahabub and Shariful Haque, ,Marketing: An Islamic Perspective', World Journal of Society Sciences (2011).

Dar, Humayon A. and John R. Presley, ,Lack of Profit Loss Sharing in Islamic Banking: Management and Control Imbalances', International Journal of Islamic Financial Services, Vol. 2, No.2 (2011).

Djamil, Fathurrahman, Hukum Ekonomi Islam: Sejarah, Teori dan Konsep, Jakarta: Sinar Grafika, cet. II, 2015.

Djamil, Fathurrahman, Penerapan Hukum Perjanjian dalam Transaksi di Lembaga Keuangan Syariah, Jakarta: Sinar Grafika, 2013.

Fathurrahman, A. Meninjau Ulang Penerapan Fractional Reserve Banking pada Perbankan Syariah. IQTISHODUNA: Jurnal Ekonomi Islam, 7(2018),. Retrieved from http:// ejournal.iaisyarifuddin.ac.i $\mathrm{d} /$ index.php/iqtishoduna/article/view $/ 231$

Irsyad, Mahmud Abdul Karim, al-Madkhal ila alIqtishad al-Islamiy, Jordania: Dar alNafais, 2011.

Karim, Adiwarman A., Islamic Banking: Fiqh and Financial Analysis, Jakarta: PT Raja Grafindo Persada, 3rd edition, 2008.

Khan, Shahrukh Rafi, ,Profit and Loss Sharing as a Substitute for Interest in Islamic Banking', Journal of Savings and Development, Vol. 11, No. 3 (1987).

Manan, Abdul, Hukum Ekonomi Islam dalam Perspektif Kewenangan Peradilan Agama, Jakarta: Kencana, 2012.

Muhammad Syafi'i Antonio, Bank Syariah: Dari Teori Ke Praktek, Jakarta: Gema Insani Press, 2001.

Otoritas Jasa Keuangan, Statistik Perbankan Syariah, 2015.

Syarbiniy, Mahmud, Taammulat fi al-Shariah alIslamiyah, Cairo: Al-Haiah al-Mashryah al-'Amah li al-Kitab, 1999.

Venardos, Angelo M, Islamic Banking \& Finance in South-East Asia: Its Development \& Future, ingapore: B \& Jo Enterprise Pte Ltd, $3^{\text {rd }}$ Edition, 2012.

Wizarah al-Auqaf," al-Mausu'ah al-Fiqhiyah alKuwaitiyah, Kuwait: Dar alShafwah, juz 38, 1998. www.bps.go.id.

www.syariahmandiri.co.id

Yahya, Muchlis dan Edy Yusuf Agunggunanto, ,Teori Bagi Hasil dan Perbankan Syariah dalam Ekonomi Syariah', Jurnal Dinamika Ekonomi Pembangunan (2011). 